\title{
Effect of Localized Irrigation on Dendrometric Attributes of Eucalyptus Hybrids
}

\author{
Isabela Braga Belchior ${ }^{1}$ (i) 0000-0003-4071-3323 \\ Adriano da Silva Lopes ${ }^{2}$ (1) 0000-0003-2211-6576 \\ Allan Motta Couto ${ }^{2}$ (1) 0000-0003-2966-6642 \\ Vitor Gabriel Marinho de Faria Pereira ${ }^{2}$ (D) 0000-0001-8374-2058 \\ Carla Deisiane De Oliveira Costa do Val ${ }^{2}$ (1) 0000-0001-5659-0570 \\ Luis Marcelo Tavares de Carvalho ${ }^{1}$ (10 0000-0003-3516-987X
}

\begin{abstract}
This study aimed to evaluate the influence of drip irrigation and micro-sprinkler on the dendrometric parameters of two Eucalyptus hybrids at 45 months. The experiment was carried out in Aquidauana, MS, using an experimental design of randomized blocks in split plot scheme. The dendrometric attributes of the trees evaluated were height, diameter at breast height, volume, shape factor, taper, and dry mass production. The Grancam hybrid has the highest growth in height, and the Urograndis has the largest diameter at breast height. Drip irrigation provides an increase of $36.7 \%$ in the wood volume of eucalyptus hybrids when compared to those that were not irrigated.
\end{abstract}

Keywords: taper, form quotient, drip irrigation, micro-sprinkler, wood volume.

\section{INTRODUCTION AND OBJECTIVES}

Forests in Brazil have been increasing fast, especially in the case of eucalyptus plantations, which represent $72.7 \%$ of the total planted forests (Ibá, 2017). Eucalyptus is an exotic genus originating in Australia (Miranda et al., 2015) and its high growth rate, its adaptive plasticity to different edaphoclimatic conditions, and the multiple uses of its wood are the causes of its preference in commercial plantations. Another relevant factor is the genetic improvement that, combined with management and silvicultural techniques, allows the use of this genus in different regions of the country (Paula et al., 2012).

Due to the rapid expansion of the planted tree sector, more information is needed on how the water used by these plantations influences dendrometric parameters, and thus forest productivity, in order to understand the balance between productivity gain and water resource conservation (Li et al., 2019). This is important especially for plantations of species of the genus Eucalyptus, which have higher water consumption and faster growth than most native species (Amazonas et al., 2018).
Water plays a fundamental role in physiological plant processes (Taiz \& Zeiger, 2017). Plants under water deficit are negatively affected, resulting in loss of turgidity, stomatal closure and altering the rate of transpiration and photosynthesis (Dombroski et al., 2014). These factors can lead to reduced plant development and, consequently, to a loss of productivity (Mitchell \& O'Grady, 2015; Taiz \& Zeiger, 2013).

With growing concern regarding water scarcity and its conscious use, coupled with the increased demand for products from eucalyptus plantations, techniques that promote forest productivity without the inappropriate use of this resource have become necessary. These techniques include genetic improvement and irrigation. Irrigation management aims to provide sufficiently controlled water at the right time (Kruashvili et al., 2016), complementing rainfall and avoiding waste of water.

Some studies have shown the importance of water in forestry, such as Bernardino et al. (2019). These authors concluded that increasing the irrigation depth also increases the survival of eucalyptus seedlings during their growing period and provides greater seedling development. While evaluating the growth

\footnotetext{
${ }^{1}$ Universidade Federal de Lavras (UFLA), Lavras, MG, Brasil

${ }^{2}$ Universidade Estadual de Mato Grosso do Sul (UEMS), Aquidauana, MS, Brasil
} 
potential of eucalyptus forests with different nutrient and water supplies, Stape et al. (2010) obtained an average increase of 30\% in productivity in irrigated treatments. Reis et al. (2006), while evaluating the field growth of eucalyptus hybrids, found higher wood volume values in irrigated treatments when compared to non-irrigated treatments, demonstrating that irrigation can be a tool for increasing forest productivity.

Thus, it is evident that irrigation can provide changes in the biometric properties of eucalyptus plantations. In this context, the objective of this study was to evaluate the influence of localized irrigation on the dendrometric parameters of the eucalyptus hybrids Urograndis and Grancam at 45 months.

\section{MATERIALS AND METHODS}

The study was conducted in the experimental irrigation area of the State University of Mato Grosso do Sul, Campus of Aquidauana (UEMS/UUA), with the following geographic coordinates: $20^{\circ} 27^{\prime} \mathrm{S}, 55^{\circ} 39^{\prime} \mathrm{W}$ and an average altitude of 207 meters. The climate of the region, according to the Köppen classification, belongs to the subtype Aw, warm tropical, sub-humid, with average annual rainfall ${ }^{\mathrm{I}}$ of $1286 \mathrm{~mm}$. The soil was identified as a dystrophic Red Argisol with a sandy texture by Schiavo et al. (2010).
The experimental area consisted of 3 hectares (ha): 1 ha for each irrigation system (drip and micro-sprinkler) and 1 ha without irrigation. The planting was carried out in April 2011 using two eucalyptus hybrids: Urograndis, clone AEC 224 (Eucalyptus urophylla $\times$ E. grandis) and Grancam, clone 1277 (Eucalyptus grandis $\times$ E. camaldulensis), with seedlings spaced at $2.25 \times 4.00 \mathrm{~m}$.

The experimental design used was randomized blocks in split plot scheme, using four blocks and two replications within each block. The plots corresponded to two irrigation systems, micro-sprinkler and drip, and a control treatment, without irrigation. The subplots were the eucalyptus hybrids Urograndis and Grancam, and each subplot was composed of 10 plants $\left(90 \mathrm{~m}^{2}\right)$, with an $8 \mathrm{~m}$ distance from each other.

The climatic data were obtained through the weather station of the Instituto Nacional de Meteorologia (INMET) in the municipality of Aquidauana, MS, until the 29th of the month after planting (MAP) and subsequently through the weather station installed at the Campus of Aquidauana, consisting of daily temperature data (maximum and minimum), relative humidity, global solar radiation, wind speed and rainfall until January 2015 (45 months after planting) (Figure 1).

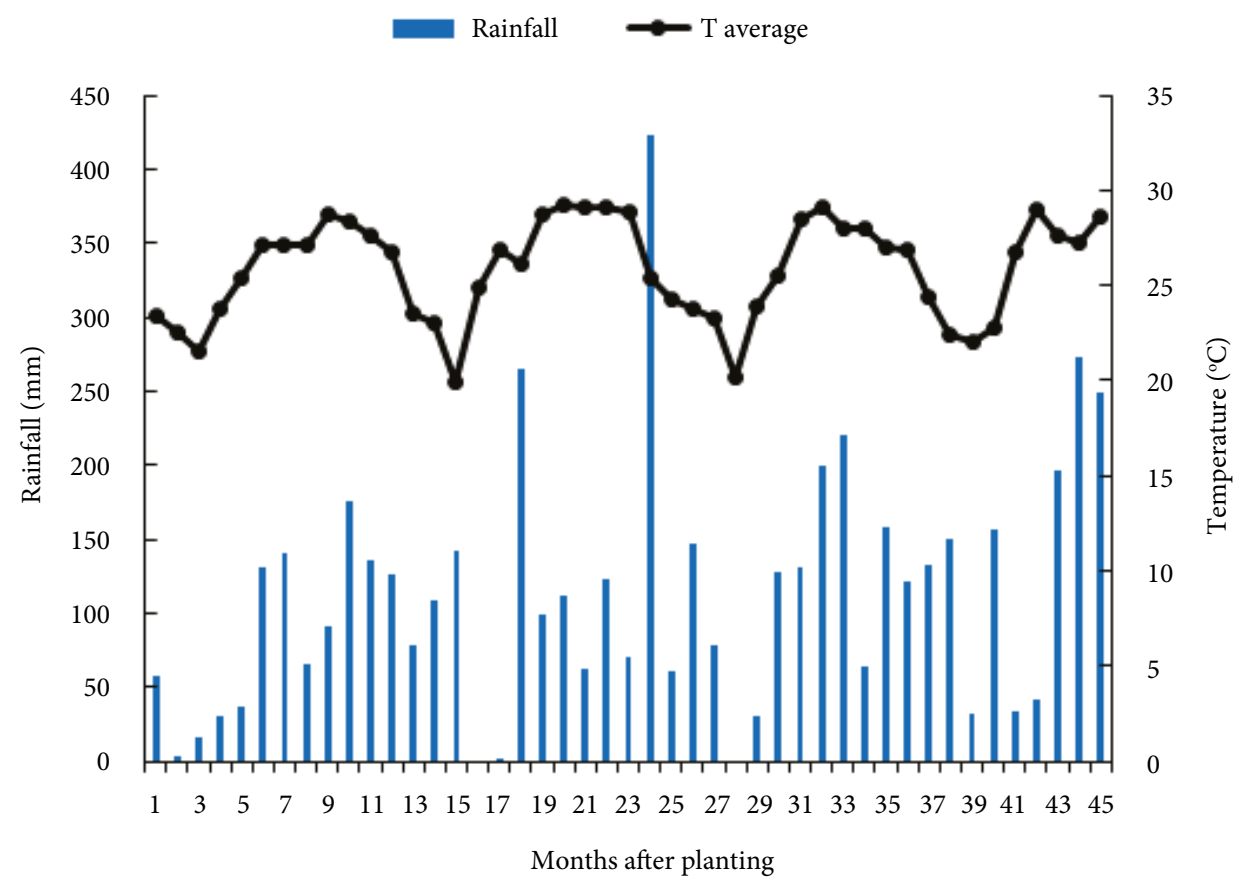

Figure 1. Monthly average rainfall and temperature data.

${ }^{\mathrm{I}}$ Average rainfall calculated from 2007 to 2015. Data collected from: https://bit.ly/32RTWOA 
For localized irrigation, micro-sprinkler with $48 \mathrm{~L} \mathrm{~h}^{-1}$ unit flow, $1.5 \mathrm{~m}$ range and $40 \mathrm{~m}$ c.a. installed at $0.3 \mathrm{~m}$ from each plant and self-compensating drippers, with $2.4 \mathrm{~L} \mathrm{~h}^{-1}$ flow and $0.5 \mathrm{~m}$ spacing between emitters, with a working pressure of $10 \mathrm{~m}$ c.a were used.

Irrigation management was based on the estimation of reference evapotranspiration from the Penman-Monteith equation (Allen et al., 1998). Crop evapotranspiration (ETc) was estimated with adaptations for localized irrigation (Bernardo et al., 2006), using the crop coefficient of 0.82 for eucalyptus (Alves et al., 2013) and a correction factor according to the localized irrigation method (Keller \& Bliesner, 1990). The percentage of wet area was calculated according to Bernardo et al. (2006).

Micro-sprinkler and drip irrigation systems resulted in $75 \%$ and $25 \%$ of wet areas, respectively. Readily available water $\left(\mathrm{RAW}_{\text {loc }}\right)$ was used as a criterion for the calculation of the irrigation depth. The depth of the root system was $970 \mathrm{~mm}$ (Reis et al., 2006) and the soil water depletion factor for conifers of 0.7, as recommended by Allen et al. (1998).

The $\mathrm{RAW}_{\text {loc }}$ was 31.1 and $93.3 \mathrm{~mm}$ for drip and microsprinkler, respectively. However, irrigation was performed whenever the sum of ETc was equal to or greater than $9 \mathrm{~mm}$, due to the high frequency and low intensity of water application, characteristic of localized irrigation.

The total irrigation depth (TID) of the implantation period up to $45^{\circ} \mathrm{MAP}$ for the micro-sprinkler system was $9.1 \%$ higher when compared to the drip system and $29.7 \%$ larger than the area without irrigation. The drip system provided an 18.9\% higher TID compared to the non-irrigated area (Table 1).

The dendrometric attributes evaluated were plant height $(\mathrm{H})$, with the aid of a digital clinometer; circumference at breast height ( $\mathrm{CBH}$ at $1.3 \mathrm{~m}$ height) using tape measure and subsequently converted to diameter at breast height (DBH at $1.3 \mathrm{~m}$ height). The wood volume $(\mathrm{V})$ was obtained by rigorous cubing of 40 selected trees in the sample units based on the diameter at the average breast height of the subplots, in which the tree closest to this value was chosen. The cubing was performed according to the Hohenadl method (Machado \& Figueiredo Filho, 2009), with section lengths established in relation to the total height and circumferences measured at $10 \%, 30 \%, 50 \%, 70 \%$ and $90 \%$ of the total height, thus calculating the total volume of the individuals.
For calculating the average wood volume per hectare, the wood volume obtained by treatment was multiplied by the number of plants per hectare (1111 individuals).

Form quotient $(\mathrm{fq})$ was obtained according to Equation 1 and the taper of trees (T) by Equation 2, adapted from Vital (2008).

$$
\mathrm{fq}=\frac{\mathrm{Vsol}}{\mathrm{Vc}}
$$

Where:

Fq: form quotient;

Vsol: solid volume (rigorous cubing);

Vc: cylinder volume.

$$
\mathrm{T}=\frac{\left(\frac{\mathrm{d} 1+\mathrm{d} 2}{2}\right)-\left(\frac{\mathrm{d} 3+\mathrm{d} 4}{2}\right)}{\mathrm{L}}
$$

Where:

T: taper (\%);

$\mathrm{d} 1$ and $\mathrm{d} 2$ : diameters of the thickest end of the $\log (\mathrm{cm})$;

$\mathrm{d} 3$ and $\mathrm{d} 4$ : diameters of the thinnest end of the $\log (\mathrm{cm})$;

L: log length (m).

Dry mass yield of irrigated and non-irrigated eucalyptus hybrids (control treatment) was also evaluated. To calculate the dry mass, the basic wood density $\left(\mathrm{D}_{\mathrm{b}}\right)$ obtained by Benites et al. (2018) was considered for the same treatments as the experimental planting under study.

The results were submitted to the analysis of variance and to Tukey's test, at $5 \%$ significance.

\section{RESULTS AND DISCUSSION}

There was no significant interaction between the analyzed factors (irrigation systems $\times$ eucalyptus hybrids). Localized irrigation (micro-sprinkler and drip) provided higher growth of plants in height when compared to non-irrigated plants $(p<0.05)$, being the major influence provided by the drip system (Table 2). Thus, it is likely that the highest growth in irrigated eucalyptus clones is due to higher water availability, reflecting higher transpiration, stomatal conductance and photosynthesis rates (Fernandes et al., 2015).

Table 1. Irrigation depth applied and total length of the implantation period up to $45^{\circ} \mathrm{MAP}$.

\begin{tabular}{lccc} 
& TID & Precipitation & ID \\
$(\mathbf{m m})$ & $(\mathbf{m m})$ & 6677.19 \\
MIC & 1527.92 & 5149.27 & 6122.84 \\
DRIP & 973.57 & 5149.27 & 5149.27 \\
CT & - & 5149.27 & \\
\hline
\end{tabular}

ID: irrigation depth; TID: total irrigation depth; MIC: micro-sprinkler; CT: control treatment. 
Studies carried out with eucalyptus species show that growth parameters decreased due to soil water deficit (Martins et al., 2008; Stape et al., 2004). Similar results were found for other forest species such as Corymbia citriodora (Abreu et al., 2015), Libidibia ferrea and Poincianella bracteosa occurring in seasonally dry tropical forests (Ferreira et al., 2015).

Plants under water stress tend to partial stomatal closure (Mugunga et al., 2015; Taiz \& Zeiger, 2013). They seek to minimize water loss through perspiration (Souza et al., 2014), thus altering gas exchange patterns, limiting the availability of $\mathrm{CO}_{2}$ within the mesophyll and reducing the rate of photosynthesis (Scalon et al., 2011), as obtained by Spokevicius et al. (2017), who found stomatal conductance and reduced sub-stomatal carbon concentration in drought conditions.

Eucalyptus hybrids also showed a significant difference $(p<0.05)$ in relation to height, with a higher value for the Grancam hybrid. This trend of higher growth in height presented at 45 months by the hybrid Grancam has been verified since its initial development (7 to 17 months) (Jung et al., 2017). It may be related to a better interaction of the genotype with the environment, which allowed its higher growth.

DBH did not differ $(p>0.05)$ between irrigated and non-irrigated trees (Table 2). This may be due to the lower water availability for non-irrigated plants. This condition may change the ethylene levels, which in turn confers a reduction in auxin transport and the redistribution of cellulose microtubules and microfibrils to a longitudinal position, causing significant lateral expansion (stem thickening) and consequent reduction in height (Ishihara et al., 2017; Taiz et al., 2017). Although no statistical difference was found for this variable, a higher DBH trend can be observed in irrigated trees.
However, DBH was influenced by genetic material $(p>0.05)$, the higher value being provided by Urograndis (Table 2). This may be related to the crossing of species, which results in characteristics of good silvicultural development, conferred by E. grandis (Sansígolo \& Ramos, 2011), besides the rusticity and good wood characteristic of E. urophylla (Mora \& Garcia, 2000). In addition, this hybrid has high adaptability to different forest sites, greater productivity and better wood quality (Montanari et al., 2007).

Drip irrigation provided greater wood volume when compared to the control treatment (without irrigation) $(p>0.05)$, and when there is water limitation there is also a significant reduction in stomatal conductance (White et al., 2016) influencing the photosynthetic process. Because of this, it can be inferred that the greater availability of water in the soil provided by irrigation favors the development of eucalyptus (Paula et al., 2012).

Studies such as Reis et al. (2006), which concluded that hybrids of E. grandis $\times$ E. urophylla and Eucalyptus camaldulensis $\times E$. spp. submitted to irrigation presented larger wood volume when compared to non-irrigated treatment, 38 months after planting, corroborate this result. Also, in a stand of Eucalyptus tereticornis, irrigation with sewage promoted an increase in wood volume (Minhas et al., 2015).

Irrigation has increased by $30 \%$ the wood volume in clonal eucalyptus plantations at eight locations in Brazil, and water supply is considered the main resource that determines plantation productivity levels in the country (Stape et al., 2010). In this sense, volumetric growth is positively related to water use and is therefore optimized by irrigation (White et al., 2016).

Table 2. Mean values of height $(\mathrm{H})$, diameter at breast height (DBH), wood volume (V), form quotient (fq) and taper (T) for the treatments.

\begin{tabular}{|c|c|c|c|c|c|}
\hline \multirow{2}{*}{ TREATMENTS } & $\mathbf{H}$ & DBH & $\mathbf{V}$ & fq & $\mathrm{T}$ \\
\hline & $\mathbf{m}$ & $\mathrm{cm}$ & $\mathrm{m}^{3}$ & & $\%$ \\
\hline Micro-sprinkler & 17.57 B & $13.59 \mathrm{~A}$ & $0.124 \mathrm{AB}$ & $0.489 \mathrm{~A}$ & $0.72 \mathrm{~A}$ \\
\hline Drip & $18.39 \mathrm{~A}$ & $13.81 \mathrm{~A}$ & $0.134 \mathrm{~A}$ & $0.484 \mathrm{~A}$ & $0.67 \mathrm{~A}$ \\
\hline Control & $15.74 \mathrm{C}$ & $12.29 \mathrm{~A}$ & $0.098 \mathrm{~B}$ & $0.516 \mathrm{~A}$ & $0.76 \mathrm{~A}$ \\
\hline CV (\%) & 2.83 & 10.00 & 19.64 & 8.13 & 13.98 \\
\hline MSD & 0.64 & 1.72 & 0.03 & 0.05 & 0.13 \\
\hline Urograndis & $16.48 \mathrm{~b}$ & $13.69 \mathrm{a}$ & $0.123 \mathrm{a}$ & $0.501 \mathrm{a}$ & $0.77 \mathrm{a}$ \\
\hline Grancam & $18.48 \mathrm{a}$ & $13.13 \mathrm{~b}$ & $0.122 \mathrm{a}$ & $0.484 \mathrm{a}$ & $0.65 \mathrm{~b}$ \\
\hline CV (\%) & 4.23 & 5.68 & 14.37 & 6.34 & 3.37 \\
\hline MSD & 0.51 & 0.52 & 0.01 & 0.02 & 0.02 \\
\hline
\end{tabular}

MSD: minimum significant difference; CV: coefficient of variation. Averages followed by the same letter in the columns do not differ statistically by Tukey's test at $5 \%$ significance level, uppercase letters represent irrigation systems and lowercase letters represent eucalyptus hybrids. 
Among the eucalyptus hybrids, no significant difference $(p>0.05)$ was observed for wood volume. This fact may be related to the higher $\mathrm{DBH}$ value provided by the Urograndis hybrid and higher height value of the Grancam hybrid, thus compensating for the volume calculation, which considers these variables.

Fq was not influenced by irrigation and there was no significant difference between eucalyptus hybrids (Table 2) $(p>0.05)$ for this variable, despite being a factor influenced by genetic material (Campos \& Leite, 2013), which may be related to hybridization, as they have E. grandis as a common species. Thus, the estimate form quotient found for the total tree volume was 0.501 for the hybrid Urograndis and 0.484 for the Grancam. Similar results were found for Eucalyptus grandis, with an average form quotient of 0.47 , obtained for individual or stand volume calculation (Miguel et al., 2010).

The taper was not influenced by irrigation $(p>0.05)$ (Table 2), so the tree growth provided by the greater availability of water does not influence the shape of the stem. Furthermore, it was observed that eucalyptus hybrids provided a difference in taper $(p<0.05)$, and Urograndis presented a higher value. This can be explained by the fact that taper is a parameter that varies depending on the species (Vital, 2008).

The taper of the Urograndis and Grancam hybrids was $0.77 \%$ and $0.65 \%$, respectively, and may be included in Class I, according to the standard for measurement and classification of hardwood logs, IBDF (1984), with taper values of less than $3 \%$ or $3 \mathrm{~cm} / \mathrm{m}$ representing logs of higher quality class (Vital, 2008). Similar results were found in a study on the evaluation of the quality of logs and lumber of eucalyptus species, with the taper obtained at $0.86 \mathrm{~cm} / \mathrm{m}$ (Hornburg et al., 2012).

When subjected to localized irrigation, the hybrids Urograndis and Grancam tended to increase the production of aerial dry biomass (Table 3). It is likely that non-irrigated plants prioritized the allocation of photoassimilates in the roots by stimulating their growth and lateral root formation to the detriment of aerial biomass production (Ryan et al., 2010; Taiz \& Zeiger, 2013). Matos et al. (2016) found investment in the root system by the eucalyptus hybrid Urocan under the condition of significant water deficit.

Plants with low water availability tend to further explore the soil profile to increase water absorption potential (Taiz \& Zeiger, 2013). Similar results were obtained in the research of Stape et al. (2004); Scalon et al. (2011); Maseda \& Fernández (2016) and Fernández et al. (2018). The authors found higher values of shoot dry mass in plants under higher water availability.

Increased productivity of planted forests can lead to changes in wood quality (Sette Júnior et al., 2012). Thus, from all wood properties, density is one of the most important and can be changed with the use of some silvicultural treatments, such as spacing, irrigation and fertigation (Sousa et al., 2010). This was not verified for the hybrid Urograndis, which did not show a tendency to decrease in $\mathrm{D}_{\mathrm{b}}$ with the use of irrigation, thus being considered more stable regarding water availability.

On the other hand, this change was verified in the Grancam hybrid when subjected to localized irrigation. This confirmed a reduction in $\mathrm{D}_{\mathrm{b}}$ values, maybe due to greater hybrid availability, which stimulates the formation of larger diameter cells in response to activation of auxin growth hormone (Taiz et al., 2017).

Thus, it is recommended to use localized irrigation (micro-sprinkler and drip) to increase productivity in eucalyptus plantations, providing conditions for the genetic material to express its productive potential; and, in particular, the use of drip systems, which has an advantage over micro-sprinkler because it applies water more efficiently and closely to the roots, increasing volumetric production and allowing a reduction in the cutting time of crops.

Table 3. Dry mass production at 45 MAP of eucalyptus (Urograndis and Grancam) hybrids irrigated, drip and control treatments.

\begin{tabular}{|c|c|c|c|c|c|}
\hline & \multirow{2}{*}{$\begin{array}{l}\text { TREATMENTS } \\
\text { m }^{3} \mathbf{h a}^{-1}\end{array}$} & \multirow{2}{*}{$\frac{\mathrm{V}}{\mathrm{mm}}$} & \multirow{2}{*}{$\frac{\text { TID }}{\mathrm{kg} \mathrm{m}^{-3}}$} & \multirow{2}{*}{$\frac{\mathrm{D}_{\mathrm{b}}^{*}}{\mathrm{~kg} \mathrm{ha}^{-1}}$} & \multirow{2}{*}{ Dry mass } \\
\hline & & & & & \\
\hline \multirow{3}{*}{ Urograndis } & Micro-sprinkler & 131.73 & 6677.19 & 342 & 45052.47 \\
\hline & Drip & 157.13 & 6122.84 & 384 & 60337.01 \\
\hline & Control & 108.32 & 5149.27 & 351 & 38021.20 \\
\hline \multirow{3}{*}{ Grancam } & Micro-sprinkler & 142.84 & 6677.19 & 402 & 57422.64 \\
\hline & Drip & 141.65 & 6122.84 & 384 & 54394.56 \\
\hline & Control & 108.32 & 5149.27 & 451 & 48853.45 \\
\hline
\end{tabular}

V: wood volume; TID: total irrigation depth; $\mathrm{D}_{\mathrm{b}}$ : basic wood density.

${ }^{\star}$ Data obtained from Benites et al. (2018). 


\section{CONCLUSIONS}

Micro-sprinkler and drip irrigation allow a higher height growth of the Urograndis and Grancam hybrids.

The Grancam hybrid grows the most in height and the Urograndis in diameter at breast height.

Drip irrigation provides an increase of $36.7 \%$ in the wood volume of eucalyptus hybrids when compared to those that were not irrigated.

Form quotient and taper are not influenced by irrigation. Taper is only influenced by the type of genetic material used.

\section{ACKNOWLEDGEMENTS}

To the Universidade Estadual de Mato Grosso do Sul (UEMS) and the Coordenação de Aperfeiçoamento de Pessoal de Nível Superior (Capes) for granting a scholarship to the first author.

\section{SUBMISSION STATUS}

Received: 30 May 2017

Accepted: 28 Aug. 2019

Associate editor: Rafaella de Angeli Curto

(D) 0000-0001-5509-4655

\section{CORRESPONDENCE TO \\ Isabela Braga Belchior}

Universidade Federal de Lavras (UFLA), Departamento de Ciências

Florestais, Laboratório de Estudos e Projetos em Manejo Florestal, Campus Universitário, CEP 37200-000, Lavras, MG, Brasil

e-mail: isabela_bbelchior@hotmail.com

\section{REFERENCES}

Abreu MC, Martins FB, Freitas CH, Pereira RAA, Melloni EGP. Valores limítrofes para transpiração, desenvolvimento e crescimento de Corymbia citriodora (Hook.) K.D. Hill \& L.A.S. Johnson em resposta à deficiência hídrica no solo. Revista Árvore 2015; 39(5): 841-852. 10.1590/0100-67622015000500007

Allen RG, Pereira LS, Raes D, Smith M. Crop Evapotranspiration: guidelines for computing crop requirements. Roma: FAO; 1998.

Alves MEB, Mantovani EC, Sediyama GC, Neves JCL. Estimate of the crop coefficient for Eucalyptus cultivated under irrigation during initial growth. Cerne 2013; 19(2):247-253. 10.1590/S0104-77602013000200008

Amazonas NT, Forrester DI, Oliveira RS, Brancalion PHS. Combining Eucalyptus wood production with the recovery of native tree diversity in mixed plantings: Implications for water use and availability. Forest Ecology and Management 2018; 418: 34-40. 10.1016/j.foreco.2017.12.006

Benites PKRM, Lopes AS, Gouvêa AFG, Silva FC, Souza CCB. Caracterização tecnológica da madeira de híbridos de eucalipto irrigados e fertirrigados. Ciência Florestal 2018; 28(4): 1716-1728. $10.5902 / 1980509835320$

Bernardo S, Soares AA, Mantovani EC. Manual de irrigação. 8th ed. Viçosa: UFV; 2006.
Bernardino LT, Bonom R, Souza JM. Desenvolvimento inicial de mudas de eucalipto sob diferentes lâminas de irrigação. Revista Brasileira de Agricultura Irrigada 2019; 13(1):3169-3179. 10.7127/ RBAI.V13N100833

Campos JCC, Leite HG. Mensuração florestal: perguntas e respostas. 4th ed. Viçosa: UFV; 2013.

Dombroski JLD, Freitas RMO, Tomczak VE, Pinto JRS, Farias RM. Ecophysiology of water stressed Handroanthus impetiginosus (Mart. Ex. DC Mattos) seedlings. Scientia Forestalis 2014; 42(101): 155-163.

Fernandes ET, Cairo PAR, Novaes AB. Respostas fisiológicas de clones de eucalipto cultivados em casa de vegetação sob deficiência hídrica. Ciência Rural 2015; 45(1): 29-34. 10.1590/0103-8478cr20120152

Fernández M, Alaejos J, Andivi E, Vázquez-Piqué J, Ruiz F, López F et al. Eucalyptus $\mathrm{x}$ urograndis biomass production for energy purposes exposed to a Mediterranean climate under different irrigation and fertilisation regimes. Biomass and Bioenergy 2018; 111: 22-30. 10.1016/j.biombioe.2018.01.020

Ferreira WN, Lacerda CF, Costa RC, Medeiros Filho S. Effect of water stress on seedling growth in two species with different abundances: the importance of Stress Resistance Syndrome in seasonally dry tropical forest. Acta Botanica Brasilica 2015; 29(3): 375-382. 10.1590/0102-33062014abb0045

Hornburg KF, Eleotério JR, Bagattoli TR, Nicoletti AL. Qualidade das toras e da madeira serrada de seis espécies de eucalipto cultivadas no litoral de Santa Catarina. Scientia Forestalis 2012; 40(96): 463-471.

Indústria Brasileira de Árvores - IBÁ. Relatório IBÁ 2017. Brasília: Pöyry; 2017.

Ishihara KL, Lee EKW, Borthakur D. Thigmomorphogenesis: changes in morphology, biochemistry, and levels of transcription in response to mechanical stress in Acacia koa. Canadian Journal of Forest Research 2017; 47(5): 583-593. 10.1139/cjfr-2016-0356

Jung LH, Lopes AS, Oliveira GQ, Oliveira JCL, Fanaya ED Jr, Brito KRM. Irrigação no desenvolvimento inicial de Eucalyptus urophylla $\mathrm{x}$ Eucalyptus grandis e Eucalyptus grandis $\mathrm{x}$ Eucalyptus camaldulensis. Ciência Florestal 2017; 27(2): 655-667. 10.5902/1980509827750

Keller J, Bliesner RD. Sprinkle and trickle irrigation. New York: Van Nostrand Reinold; 1990.

Kruashvili I, Bziava K, Inashvili I, Lomishvili M. Determination of optimal irrigation rates of agricultural crops under consideration of soil properties and climatic conditions. Annals of Agrarian Science 2016; 14(3): 217-221. 10.1016/j.aasci.2016.08.006

Li X, Farooqi TJA, Jiang C, Liu S, Sun OJ. Spatiotemporal variations in productivity and water use efficiency across a temperate forest landscape of Northeast China. Forest Ecosystems 2019; 6: 22. 10.1186/ s40663-019-0179-x

Machado SA, Figueiredo Filho A. Dendrometria. 2nd ed. Guarapuava: Unicentro; 2009.

Martins FB, Streck NA, Silva JC, Morais WW, Susin F, Navroski MC et al. Deficiência hídrica no solo e seu efeito sobre transpiração, crescimento e desenvolvimento de mudas de duas espécies de eucalipto. Revista Brasileira de Ciência do Solo 2008; 32(3): 1297-1306. 10.1590/S0100-06832008000300037 
Maseda PH, Fernández RJ. Growth potential limits drought morphological plasticity in seedlings from six Eucalyptus provenances. Tree Physiology 2016; 36(2): 243-251. 10.1093/treephys/tpv137

Matos FS, Oliveira PRC, Gil JLRA, Sousa PV, Gonçalves GA, Sousa MPBL et al. Eucalyptus urocan drought tolerance mechanisms. African Journal of Agricultural Research 2016; 11(18): 1617-1622. 10.5897/AJAR2016.10918

Minhas PS, Yadav RK, Lal K, Chaturvedi RK. Effect of long-term irrigation with wastewater on growth, biomass production and water use by Eucalyptus (Eucalyptus tereticornis Sm.) planted at variable stocking density. Agricultural Water Management 2015; 152: 151-160. 10.1016/j.agwat.2015.01.009

Miguel EP, Canzi LF, Rufino RF, Santos GA. Ajuste de modelo volumétrico e desenvolvimento de fator de forma para plantios de Eucalyptus grandis localizados no município de Rio Verde - GO. Enciclopédia Biosfera 2010; 6(11): 1-13.

Miranda DLC, Junior VB, Gouveia DM. Fator de forma e equações de volume para estimativa volumétrica de árvores em plantio de Eucalyptus urograndis. Scientia Plena 2015; 11(3): 1-8.

Mitchell PJ, O'Grady AP. Adaptation of leaf water relations to climatic and habitat water availability. Forests 2015; 6(7):2281-2295. 10.3390/ f6072281

Montanari R, Marques J Jr, Campos MCC, Cavalcante IHL. Níveis de resíduos de metalurgia e substratos na formação de mudas de eucalipto (Eucalyptus Urograndis). Revista de Biologia e Ciência da Terra 2007; 7(1): 59-66.

Mora AL, Garcia CH. A cultura do eucalipto no Brasil. São Paulo: SBS; 2000.

Mugunga C, Kool D, Van Wijk MT, Mohren GMJ, Giller KE. Water use by short rotation Eucalyptus woodlots in southern Rwanda. Agroforestry Systems 2015; 89(6): 1119-1139. 10.1007/s10457-015-9843-5

Paula RR, Pereira MG, Santiago RR, Amorim HB. Propriedades edáficas e desenvolvimento de eucalipto em topossequência na Flona Mário Xavier-RJ. Floresta e Ambiente 2012; 19(3): 344-351. 10.4322/floram.2012.040

Ryan MG, Stape JL, Binkley D, Fonseca S, Loos RA, Takahashi EM et al. Factors controlling Eucalyptus productivity: How water availability and stand structure alter production and carbon allocation. Forest Ecology and Management 2010; 259(9): 1695-1703. 10.1016/j.foreco.2010.01.013

Reis GG, Reis MGF, Fontan ICI, Monte MA, Gomes AN, Oliveira CHR. Crescimento de raízes e da parte aérea de clones de híbridos de Eucalyptus grandis x Eucalyptus urophylla e de Eucalyptus camaldulensis $\mathrm{x}$ Eucalyptus spp. submetidos a dois regimes de irrigação no campo. Revista Árvore 2006; 30(6): 921-931. 10.1590/ S0100-67622006000600007

Sansígolo CA, Ramos ES. Qualidade da madeira e da celulose de um clone de Eucalyptus grandis plantado em três locais. Cerne 2011; 17(1): 47-60. 10.1590/S0104-77602011000100006

Scalon SPQ, Mussury RM, Euzébio VLM, Kodama FM, Kissmann C. Estresse hídrico no metabolismo e crescimento inicial de mudas de mutambo (Guazuma ulmifolia Lam.). Ciência Florestal 2011; 21(4): 655-662. 10.5902/198050984510

Schiavo JA, Pereira MG, Miranda LPM, Dias Neto AH, Fontana A. Caracterização e classificação de solos desenvolvidos de arenitos da formação Aquidauana-MS. Revista Brasileira de Ciência do Solo 2010; 34(3): 881-889. 10.1590/S0100-06832010000300029

Sette CR Jr, Oliveira IR, Tomazello Filho M, Yamaji FM, Laclau JP. Efeito da idade e posição de amostragem na densidade e características anatômicas da madeira de Eucalyptus grandis. Revista Árvore 2012; 36(6): 1183-1190. 10.1590/S0100-67622012000600019

Sousa GC, Silva JV, Costa CC. Efeitos dos tratos silviculturais na produtividade e na qualidade da madeira em plantações de Eucalyptus spp. Revista Agrogeoambiental 2010; 2(2): 35-44. 10.18406/2316-1817v2n22010271

Souza AT, Streck NA, Heldwein AB, Bisognin DA, Winck JEM, Rocha TSM et al. Transpiration and leaf growth of potato clones in response to soil water deficit. Scientia Agricola 2014; 71(2): 96-104. 10.1590/S0103-90162014000200002

Spokevicius AV, Tibbits J, Rigault P, Nolin MA, Müller C, Merchant A. Medium term water deficit elicits distinct transcriptome responses in Eucalyptus species of contrasting environmental origin. BMC Genomics 2017; 18(1): 284. 10.1186/s12864-017-3664-Z

Stape JL, Binkley D, Ryan MG, Nascimento Gomes A. Water use, water limitation, and water use efficiency in a Eucalyptus plantation. Bosque 2004; 25(2): 35-41. 10.4067/S0717-92002004000200004

Stape JL, Binkley D, Ryan MG, Fonseca S, Loos RA, Takahashi EN et al. The Brazil Eucalyptus Potential Productivity Project: influence of water, nutrients and stand uniformity on wood production. Forest Ecology and Management 2010; 259(9): 1684-1694. 10.1016/j.foreco.2010.01.012

Taiz L, Zeiger E. Fisiologia vegetal. 5th ed. Porto Alegre: Artmed; 2013.

Taiz L, Zeiger E, Moller IM, Murphy A. Fisiologia e desenvolvimento vegetal. 6th ed. Porto Alegre: Artmed; 2017.

Vital BR. Planejamento e operação de serrarias. Viçosa: UFV; 2008.

White D, Beadle C, Worledge D, Honeysett J. Wood production per evapotranspiration was increased by irrigation in plantations of Eucalyptus globulus and E. nitens. New Forests 2016; 47: 303-317. 10.1007/s11056-015-9516-2 